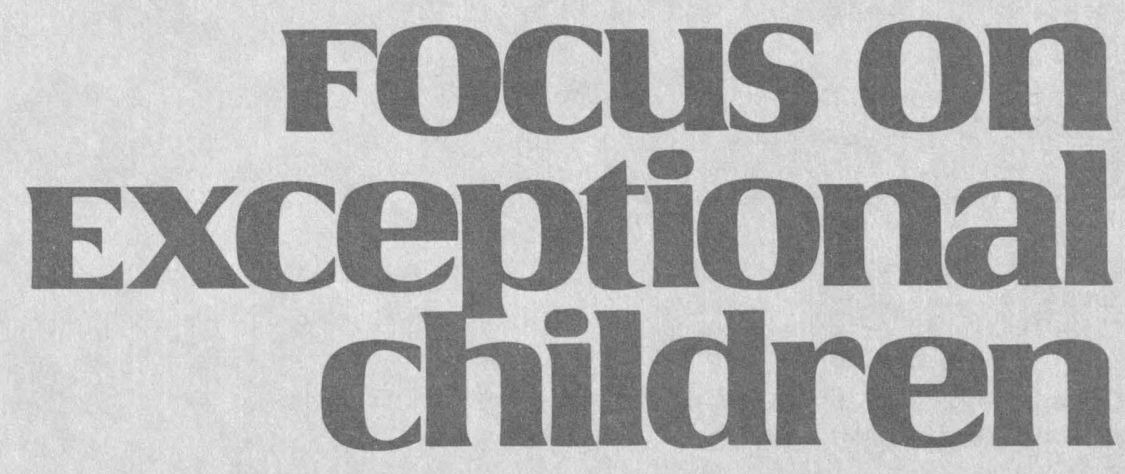

\title{
Assessment and Placement of Handicapped Pupils Into Secondary Vocational Education Programs
}

\section{R. Brian Cobb and Dave Larkin}

As educational alternatives develop and evolve, so too must assessment strategies. Prior to the 20th century, assessment was primarily a matter of monitoring competence in the "three Rs." During the early 1900s, as the Industrial Revolution reshaped the way we worked, vocational education curricula (primarily agriculture, industrial arts, and home economics) appeared as a means to provide a well-trained labor force. During this same time, compulsory education and child labor laws required our schools to educate an ever increasing range of pupils, foreshadowing the need for a general education curriculum track. It is not surprising, then, that the early $1900 \mathrm{~s}$ marked the beginning of the standardized testing movement. School counselors and administrators needed a means to place students into the various curriculum alternatives.

As we progressed through the first half of the 1900s, curriculum options expanded even more. New divisions such as health, distributive, business, and technical education appeared in vocational education, and our increasingly sophisticated assessment techniques opened the door for placement among special education alternatives. The 1950 s and early 1960s saw a rapid expansion in school placement alternatives in mental retardation, followed closely by the learning disabilities category in the 1970 s and, more recently, that of emotional disturbance/behavioral disorders.

The expanding curriculum alternatives and the inclusion of children with a greater range of abilities and needs has made educators increasingly aware of complex interactions among curriculum, instructional delivery, and child characteristics. One small, yet troublesome, portion of that interaction - the assessment and placement of handicapped students who are likely candidates to receive secondary vocational education in a mainstreamed environment-is the subject of this article. The discussion here relates only to high school vocational assessment, and it is not intended to be critical of all of current vocational evaluation, both within and outside of schools. We recognize that the quality of vocational evaluation ranges to extremes. Our aim is to be constructive, not perjorative, and we trust the reader will apply that intent to the following discussion and paradigm.

Brian Cobb is an Assistant Professor in the Department of Special Education, University of Maryland. Dave Larkin is an Assistant Professor in the Department of Professional Education, Bemidji State University.

C Love Publishing Company, 1985 


\section{BACKGROUND AND CURRENT PROBLEMS}

Assessment of handicapped students in our public schools has occurred in systematic, albeit varied forms for several decades now. With the mandates in the PL 94142 legislation associated with non-biased testing, least restrictive placements, and multidisciplinary staffing teams, the propriety and utility of many of our school assessment practices have come under intense scrutiny (for recent examples of critiques from several different perspectives, see Messick, 1984, Ysseldyke \& Mirkin, 1982; Snow, 1984; Leinhardt, Bickel, \& Pallay, 1982; Lilly, 1983). At a minimum, traditional practices in assessment for screening, placement, and program planning in special education seem to have become confounded by technical, methodological, and functional service delivery issues.

Although the empirical research base is not nearly as extensively developed, these same kinds of problems seem to hold for vocational/special education assessment as well. We have recognized for years the value of the vocational assessment process for handicapped students, including those with mildly handicapping conditions. These processes are commonly perceived to yield

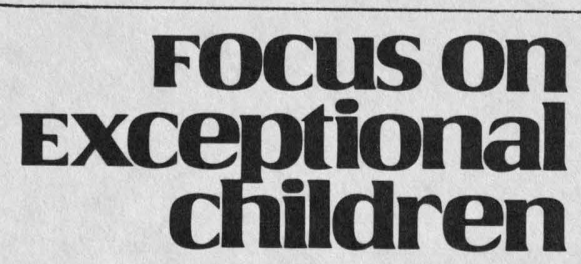

FOCUS ON EXCEPTIONAL CHILDREN (ISSN0015-511X) (USPS 203-360) is published monthly except June, July, and August as a service to teachers, special educators, curriculum specialists, administrators, and those concerned with the special education of exceptional children. This journal is abstracted and indexed in Exceptional Child Education Resources, and is also available in microform from Xerox University Microfilm. Ann Arbor, Michigan. Subscription rates, $\$ 18.00$ per year. Copyright $\odot$ 1985. Love Publishing Company. All rights reserved. Reproduction in whole or part without written permission is prohibited. Printed in the United States of America. Second class postage is paid at Denver, Colorado.

POSTMASTER: Send address changes to:

Love Publishing Company

Executive and Editorial Office

1777 South Bellaire Street

Denver, Colorado 80222

Telephone (303) 757-2579

\section{EDITORIAL BOARD}

$\begin{array}{cc}\text { Edward L. Meyen } & \text { Glenn A. Vergason } \\ \text { University of Kansas } & \text { Georgia State University }\end{array}$

Richard J. Whelan

University of Kansas Medical Center

Stanley F. Love

Publisher
Carolyn Acheson Senior Editor extrinsic benefits for a particular student in terms of team planning and placement decisions, and intrinsic rewards in the student's growth in confidence and maturity vis-avis the world of work. Recently, school guidance personnel and psychologists have recognized the potential that vocational assessment can play in their work in the schools (see, for example, Hohenshil, 1984; Shepard, Dielman, \& Ellenwood, 1984; entries in Hohenshil, Anderson, \& Salwan, 1982; Batsche, 1982; Peterson \& Housley, 1982). These school personnel, however, have also expressed chagrin over many aspects characterizing much of traditional vocational assessment (Zytowski, 1982; Thurlow \& Ysseldyke, 1982).

It seems evident, then, that vocational assessment of handicapped students will continue to demand the attention of professional vocational and special educators. This assessment area received a tremendous impetus in the 1960s with parallel development of the fields of vocational evaluation in rehabilitation and the civil rights focus on individual needs in education. In the 1970s vocational assessment again received attention as a result of the symbiotic relationship established in the PL $94-482$ and PL 94-142 laws. Mainstreamed enrollments in regular vocational education have increased (Phelps, 1982), and programs and services have expanded, although at uneven rates (Wright, Cooperstein, Renneker, \& Padilla, 1982). The new vocational education legislation (The Carl D. Perkins Vocational Education Act of 1984- H.R. 4164) has strengthened both the fiscal and the programmatic attention that handicapped students must receive in vocational education. Indeed, vocational assessment appears specifically in legislative language for the first time.

Historically, vocational assessment has been perceived by virtually all special education professionals as a fundamentally important supportive service for handicapped adolescents. Model processes have evolved in many states (e.g., Maryland State Department of Education, 1980; Arizona Department of Education, 1982; Peterson \& Hill, 1982; California State Department of Education, 1983), and it is not unusual for school districts to require all handicapped students who enroll in a vocational education course to undergo comprehensive, formal vocational evaluation. A common theme underlying all models of vocational assessment is that results from that process should be used in developing the IEP (Phelps \& McCarty, 1984), although local policy requiring the use of vocational assessment results in IEP processes is much less frequent.

This burgeoning evolution of vocational assessment models and processes notwithstanding, difficulties remain in the development of a consistent vocational assessment process that fulfills an equally useful function 
for parents, educators, support personnel, and students alike. Although considerable overlap exists, these areas will be discussed in terms of: (a) problems with the relationship between vocational assessment and vocational evaluation, and (b) definition of the process and environmental constructs assessed.

\section{The Relationship between Vocational Assessment and Vocational Evaluation}

Those describing the vocational assessment process have yet to achieve a consensus about what is meant by vocational evaluation and vocational assessment and how the two differ, if at all. These distinctions are more than just semantic, as evidenced by the extreme variability in the perceived relationship between the two. Consider the following examples.

Sitlington and Wimmer (1978), in an often cited article on vocational assessment, began:

\footnotetext{
The terms vocational assessment and vocational evaluation have been used to mean anything from a l-week deluge of aptitude and interest tests to a 3- to 4-week period of data collecting using a wide variety of assessment procedures. (p. 74)
}

The clear implication here is one of synonymy; the authors did nothing in the remainder of their manuscript to dispel that notion. Other writers have concurred. Several authors, however, have attempted to differentiate between the two. Unfortunately, no two seem to differentiate the relationship consistently.

Peterson (1982), who chaired a National Association of Vocational Education Special Needs Personnel (NAVESNP) task force on vocational assessment and produced a draft position paper in that effort, views vocational assessment as a comprehensive and systematic process, of which vocational evaluation is but a subcomponent. Just the reverse status is assigned by Kiernan and Petzy (1982), who stated:

The terms vocational assessment and vocational evaluation are often used interchangeably. In this chapter, a distinction is drawn between assessment - as a process in which a characteristic factor is appraised in order to assign it a rating, description, or score - and evaluation - as a process in which data or information derived from an assessment is analyzed in order to determine its value in light of specific decisions that must be made. (p. 118)

Thus, these authors are telling us that vocational assessment is synonymous with test administration and vocational evaluation is the larger act of putting those assessment (test) results to use. This interpretation is not only at odds with Peterson's (1982) but is also counter to how most assessment specialists in special education perceive testing vis-a-vis assessment.
We believe that an effort to distinguish between the two terms as they relate to child assessment is counterproductive. What is needed in child assessment is a distinction between the many purposes for which vocational assessments are conducted rather than a distinction between the terms assessment and evaluation. We propose to eliminate the term vocational evaluation as it pertains to the entire range of assessment activities associated with screening, placement, and program planning and monitoring for an individual child. If local or state education personnel want to evaluate (assess merit or worth) local service delivery at the programmatic level, the term vocational evaluation may have some utility. For purposes of this article, however, we believe one should assess individuals (and their match with curriculum and instructional delivery) and evaluate programs.

\section{Definition of Vocational Assessment and Environmental Constructs Assessed}

Related to the problem of distinguishing between vocational assessment and vocational evaluation is that of defining the process. Again, the literature is equivocal stemming from confusion about the variety of purposes for which vocational assessment might be conducted, as well as confusion about what constructs are being assessed. Although conceptually separating these two issues from each other is impossible, we will treat them separately to make our position clearer.

\section{Definition of Vocational Assessment}

It would seem that whether it is vocational assessment or vocational evaluation, the definition of that process would be relatively consistent. Not so. Definitional disparities appear to gravitate toward an emphasis on predicting an individual/employment "fit" at one extreme, to a more exploratory, learning-centered, and schoolbased approach at the other extreme. An example of the former is provided by Botterbusch (1978):

Vocational assessment is the process of assessing a person to determine the specific nature of his or her aptitudes, skills, characteristics, and work-related behaviors. (p. 2)

Knowledge derived through this assessment process is then matched with what is known about the knowledge, skills, and abilities requisite in a particular occupation. The ultimate purpose is to generate an occupational profile of a handicapped individual and match that with occupational information from specific jobs, most often through the Dictionary of Occupational Titles or some similar manual. 
Contrast the above definition with the following definitions of vocational assessment:

\begin{abstract}
. a comprehensive process conducted over a period of time, involving a multi-disciplinary team. . . with the purpose of identifying ind ividual characteristics, education, training, and placement needs, which provides educators the basis for planning an individual's program. (Dahl, Appleby, \& Lipe, 1978, p. 103)
\end{abstract}

or

.a holistic approach which considers an individual's total career development. . . [whose purpose] is to collect and provide objective career information for parents, educators, the student, and others to use in planning appropriate educational experiences to enhance the student's employability. (Peterson \& Hill. 1982, p. 1)

We believe these latter definitions convey a much more utilitarian process at the public school level. As has been pointed out repeatedly (Zytowski, 1982; Phelps \& Wentling, 1977; Dunn, 1976), our instrumentation is simply not advanced enough to make accurate predictive decisions about handicapped adolescents' occupational traits or abilities. As a result, some profoundly mistaken assumptions about the employment potential of a handicapped student may be made at the local level.

\section{Environmental Constructs Assessed}

No doubt the confusion about the definition of the terms is associated, in large measure, to the lack of clarity about what is being assessed. This construct validity problem is compounded by the nature of vocational education and the origin of vocational assessment within the realm of vocational rehabilitation.

Formal vocational assessment, as it has evolved in the public schools and has typically been described in the literature, has been directly adapted from the vocational rehabilitation evaluation process. This process is grounded in predictive attempts to assess disabled adults for a "fit" with workplace requirements, either through competency-based assessment procedures, occupational trait analysis, or a behavioral consistency approach (Dunn, 1976). This model can be considered "diagnosticprescriptive" in that the assessment attempts to diagnose individual vocational interests/aptitudes and results in a prescription of how those client characteristics can be matched with suitable workplace requirements. (Much more detailed discussions of this process are available in Schneck, 1981; Dunn, Korn, \& Andrew, 1976.)

On the surface, then, transfer to the special/vocational education environment would appear to be appropriate, since special education service delivery has taken primarily a diagnostic-prescriptive model approach. Unfortunately, though, the "prescriptive" component of this rehabilitation assessment model does not adapt well to the didactic purposes that underlie educational functions. Hence, vocational assessment processes in our schools have evolved attempting to make predictions about employment suitability, but not very often about curricular ecology. Thus, our instructional planning personnel are confronted with vocational assessment systems and instrumentation that yield information essentially unrelated to, or only tangentially related to, curriculum.

Increasingly in recent years, this anomaly in service delivery has received critical attention in the literature (Cobb, 1981, 1983; Halpern, Lehmann, Irvin, \& Heiry, 1982; Gugerty \& Crowley, 1982; Menchetti, Rusch, \& Owens, 1982; Miller, Sachs, \& Stadt, 1982; Petzy, 1983; Rosenberg \& Tesolowski, 1982; Stodden \& Ianacone, 1981; Zytowski, 1982). The Halpern et al. (1982) book has described this dualistic approach to conceptualizing vocational assessment in terms of traditional versus contemporary approaches. Traditional assessment:

\footnotetext{
has been based upon the assumption that measures of existing aptitudes, interests, and traits can be used to predict subsequent learning, performance, and adjustment.
}

\section{Contemporary assessment, on the other hand:}

. refers to those practices that clearly link the purposes and
outcomes of assessment with the goals and techniques of instruc-
tion and other forms of service intervention. ... (p. 1)

The authors then elaborated upon the differences between the two approaches:

Rather than rely on traits or aptitudes to infer performance, the contemporary approach emphasizes the importance of direct assessment of actual competencies, [and] requires the outcomes of measurement to have direct implications for program planning. (p. 4)

We believe the contemporary notion of vocational assessment for handicapped adolescents represents the most viable and responsive assessment alternative, given the didactic purpose of vocational education. Linking assessment procedures directly to instruction is inherently more opportunity-expanding, and, we believe, may lead in general to less restrictive placements in vocational education. Most assessment models for use with mildly handicapped students, however, are bereft of systematic components that assess the match between a student's skills and deficits on the one hand and classroom curriculum, ecology, instructional delivery, and availability of supportive services on the other. What is clearly needed in our conceptualization of vocational assessment at the school level is the addition of a systematic process that includes this component as well. 


\section{A PARADIGM OF VOCATIONAL ASSESSMENT}

A logical paradigm for vocational assessment that relates the activities and instrumentation to instructional delivery has been repeatedly utilized in the regular special education assessment literature (e.g., Salvia \& Ysseldyke, 1981; Hawkins, 1979) and has more recently been characterized by Halpern et al. (1982) as falling within the contemporary assessment domain discussed earlier. What makes our paradigm different in its utility for model development is that it relates activities to instructionally relevant purposes rather than to processes and instrumentation that have characterized much of the model literature to date. We believe that if educational professionals perceive a clear chronological sense of why assessment occurs and how those notions relate to ongoing school-based activity for an individual student, the utility of the entire process will be greatly enhanced.

In this paradigm the vocational assessment process is assigned five chronological purposes: screening, placement, program planning, monitoring of individual progress, and individual program evaluation. Figure 1 depicts the chronology of these five purposes. Each of these purposes is discussed here, with examples of instrumentation and processes relative to the vocational assess-

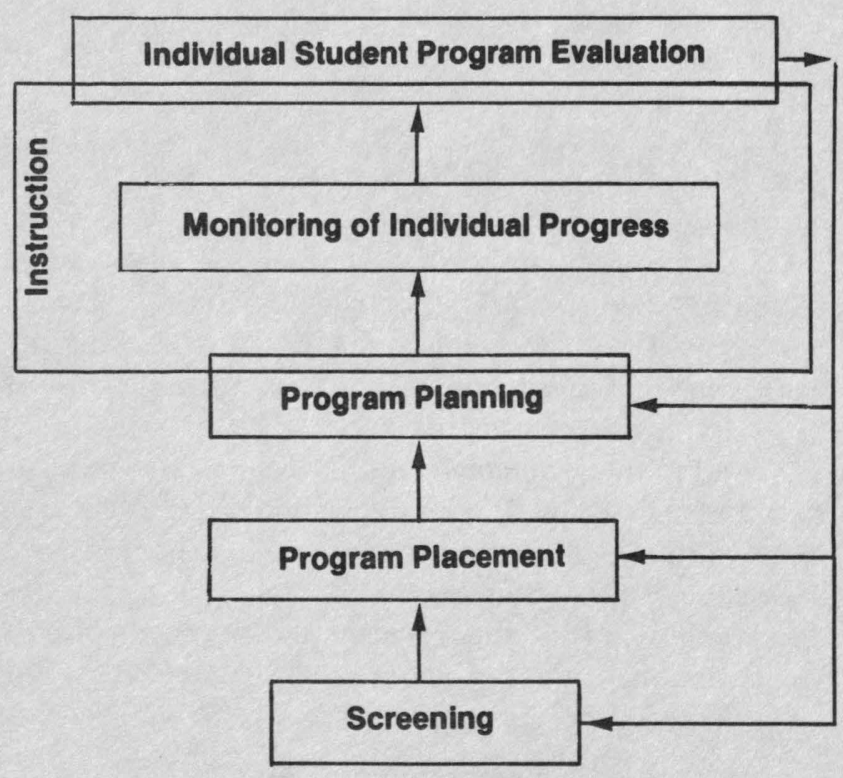

FIGURE 1

Purposes of Assessment and Their Relationship to Ongoing Instructional Delivery ment of handicapped learners in mainstreamed settings. For similar and highly compatible resources and example documents, the reader could refer to Albright, Fabac, and Evans, 1978; Albright, 1979.

A fundamental underlying assumption of this model, it should be pointed out, is a team approach to vocational assessment. We do not adhere to the more traditional assessment processes characterized by a vocational evaluator conducting an in-lab assessment, collecting information from outside sources, and synthesizing those data into an assessment report. We believe vocational, special, and regular educators can and should conduct some of the assessment activities (with proper training), not only pass judgment on the information derived from them. Thus, our assessment specialist must recognize the need for and propriety of having some assessments conducted in completely normalized settings by regular education professionals.

Each of the purposes discussed here fits well within the IEP process model as well. By indexing each of these purposes to the multiple processes in IEP development and implementation, we anticipate increasing the use of vocational assessment results in IEP development and making the IEP a more dynamic component of ongoing instruction.

\section{Screening}

Vocational assessment for the purpose of screening is the first component in our paradigm. It can be conceptualized in terms of the fundamental question a staffing team may want to answer: "Is vocational education an appropriate curriculum option for this particular handicapped student, or should he/she be in some other curriculum such as college preparatory or general track?" This question assumes that a viable set of curriculum alternatives exists and that the choice between them can be based upon direct assessment information rather than local district policy.

How do we determine whether vocational education is appropriate for a particular student? The traditional assessment approach would suggest a set of standardized procedures to determine aptitudes and interests, then try to match them with existing vocational curricula through a primarily predictive process. To screen a student for vocational education, however, we suggest the following less formal (standardized) activities.

First, we suggest using parent input as to their aspirations for the child. Bellamy and Wilcox (1982) recently introduced the notion of opportunity costs in the selection of curriculum alternatives for secondary-aged handicapped students. By the time a student reaches high 
school, he/she has only a few school years left in which to prepare for the complex demands of participatory citizenship. Many students still need remedial education in academics, domestic living, and recreating, as well as employment preparation. Parents are likely to provide important validation of a curriculum selection such as vocational education.

Parent input by itself, however, is not enough. Equally important, students at the secondary level are capable of self-selection, and vocational assessment personnel must determine whether a student is committed to that choice. We recommend a review of the student's previous scholastic record in industrial arts or prevocational coursework, as well as interviews with his/her teachers in those subjects.

Assuming the student and/or parent(s) favors placement in vocational education, assessment personnel must then determine whether program alternatives exist and are accessible. Questions the vocational assessor should address include:

1. To what extent does the school district and/or regional vocational center policy promote accessibility of programs to handicapped students exhibiting skill deficits similar to those possessed by this student?

2. To what extent is the individual ready for vocational education?

3. How well-trained and receptive are teachers in the regional vocational center toward teaching handicapped students?

4. How well does the related services system function so that success is likely? Related services should be broadly defined to include not only in-school support but also transportation, sending school guidance/counseling, etc.

\section{Placement}

Once a student has been screened and a decision has been made that vocational education is the appropriate curriculum option, the next decision that must be made is: "Which program within vocational education?" Currently, vocational education is made up of nine different divisions, although all may not be available at every vocational school.

\section{School-related Options}

These are: (1) agriculture, (2) trades and industrial, (3) business and office occupations, (4) distributive, (5) technical, (6) home economics, (7) health occupations, (8) industrial arts, and (9) cooperative education.
Within each division a variety of program alternatives may be available. For example, a student may be interested in agriculture education; yet the diversity of occupational preparation alternatives within that option might range from ornamental horticulture to agribusiness technology. Likewise, with health occupations, selections may vary from a program to train nurses'aides to one preparing laboratory technicians. Consistent with the notions of free appropriate public education and least restrictive environment, assessment for placement assumes the existence of bona fide choices for students with handicapping conditions. If local district policy presupposes the placement of all students with a particular handicapping condition in food services, for example, assessment for placement becomes superfluous.

What mechanisms and information sources can assist in assessment for placement? Again, parents can provide important information in deciding program selection. And the student, through interviews and informal interest inventories and tours of different programs, can clearly focus the selection process.

As in assessment for screening, a number of programmatic variables must be considered along with student and parent interests. For example, assessing the match between student academic skills and entry-level program competencies would be important. Similarly, some sense of a likelihood for achieving exit-level competencies must be taken into account, since mainstreamed placements should require that students achieve the same competency levels, if not the same range of competencies, as nonhandicapped students.

Another critical variable may well be the characteristics of instructional delivery. A vocational assessor's brief observation of vocational teacher teaching-styles may assist greatly in making placement decisions. Likewise, the use of teaching strategies such as peer teaching and peer tutoring, multiple media in lecture, and logical, well-sequenced presentations may be important variables in selecting a placement.

An additional concern may be the physical requirements associated with multiple locations of instruction. A building trades program is likely to require that a majority of instructional time take place at a building site. Given that on-site instruction may be much less structured than in-class instruction, a student requiring close supervision might not best be placed in that curriculum.

A placement consideration that may be extremely important is the existence of a cooperative work education (CWE) experience culminating the program selection or concurrent with it. A recent 4-year follow-up study of mildly to moderately handicapped graduates of vocational programs in Vermont suggested that part- 
time employment prior to leaving school greatly enhanced the employment prospects of those individuals (Hasazi \& Gordon, 1982). A CWE experience features paid work placement in the community in an occupation for which training has occurred during a student's vocational education program. Typically, CWE experiences occur in the final semester of a student's program and involve a half-day of work and a half-day of instruction.

Evans and Herr (1978) have also characterized the advantages of CWE programs as follows:

\begin{abstract}
Cooperative work education stimulates desirable attitudes toward work. Work atmosphere is extremely difficult to reproduce outside of a real work situation, and the importance of promptness and regular attendance at work are much more demonstrable on the job than in school. Moreover, because of the difficulty of marketing goods and services produced within school laboratories, it is also extremely difficult in laboratorybased programs to develop realistic attitudes towards speed, quality, and efficiency. (p. 238)
\end{abstract}

These authors continued by documenting extremely high employment rates of CWE completers - often as high as $80 \%$ in many school districts. Thus, the value of a CWE component in programs for mildly to moderately handicapped students is particularly compelling.

Equally important to a CWE placement in a business outside of the school may be an in-school entrepreneurial experience. Stern (1984) recently found that participants in school-based work enterprises viewed these activities, when compared to out-of-school jobs, as providing "more opportunity to work in teams, to learn skills they think will be valuable in future jobs, and to experience work that is more intrinsically motivating" (p. 422). Given that work attitudes and overall career maturity are frequently cited by employers as important qualities in prospective employees, high-quality school-based enterprises that are attached to a vocational program (such as the school store in a distributive education program) may be an important placement consideration for a handicapped youngster.

\section{Job Availabilit}

Finally, local job availability may be a prime consideration (assessment technique) for determining program selection. We place little emphasis upon predicating program selection decisions upon community employment opportunities existing at the time of placement in a training program. In many communities the jobs most available are those requiring little or no prior training, such as many of those in the fast-food industry. Mildly handicapped students are no more in need of job-specific training for these positions than are nonhandicapped students. Students should be placed in vocational education programs for jobs that legitimately require or make use of job-specific training. It is no more appropriate to let job availability in these businesses overly affect program selection decisions (such as food service programs) for mildly handicapped students than for nonhandicapped students.

Local vocational education programming has a history of responsiveness to local employer needs. Although that responsiveness has been much more evident at the postsecondary level than at the secondary level, these natural controls for determining the entire range of local vocational education programs are as satisfactory for mildly handicapped students as for nonhandicapped students. The risk of imperfections in the existing system of natural controls is preferable to the stereotypical response of over-enrolling handicapped students in training programs for "least preferred" employment.

\section{Program Planning}

Assessment for the purpose of program planning represents one of the most traditional notions of why special educators should assess their students. Yet, in the vocational assessment literature its treatment is markedly absent or underdeveloped. Overall, vocational assessment specialists are attempting to answer the question: "What support service(s) must be provided for this student to ensure success in this placement?" As with regular special education service delivery, development of the vocationally-related component to the IEP evolves in this process as well. Halpern et al. (1982) discussed this assessment component:

\footnotetext{
The development of specific goals and objectives is the major activity within program planning. If this is done in a "behavioral" fashion, specifying expected performance of the student, the articulation of performance criteria will also emerge from the planning process, along with the stipulation of "targeted" services that directly address the stated objectives. (p. 16)
}

Thus, the specification of annual goals and short-term behavioral objectives directly relating student deficits to placement curriculum results from this process, in addition to a specification of the necessary supportive services.

How is this accomplished? To best explain our notion of assessment for program planning, we will first fit this process into an ecological perspective. Figure 2 depicts this ecological perspective and suggests that a host of variables (and interactions between them) should be examined in the identification of goals, objectives, and 


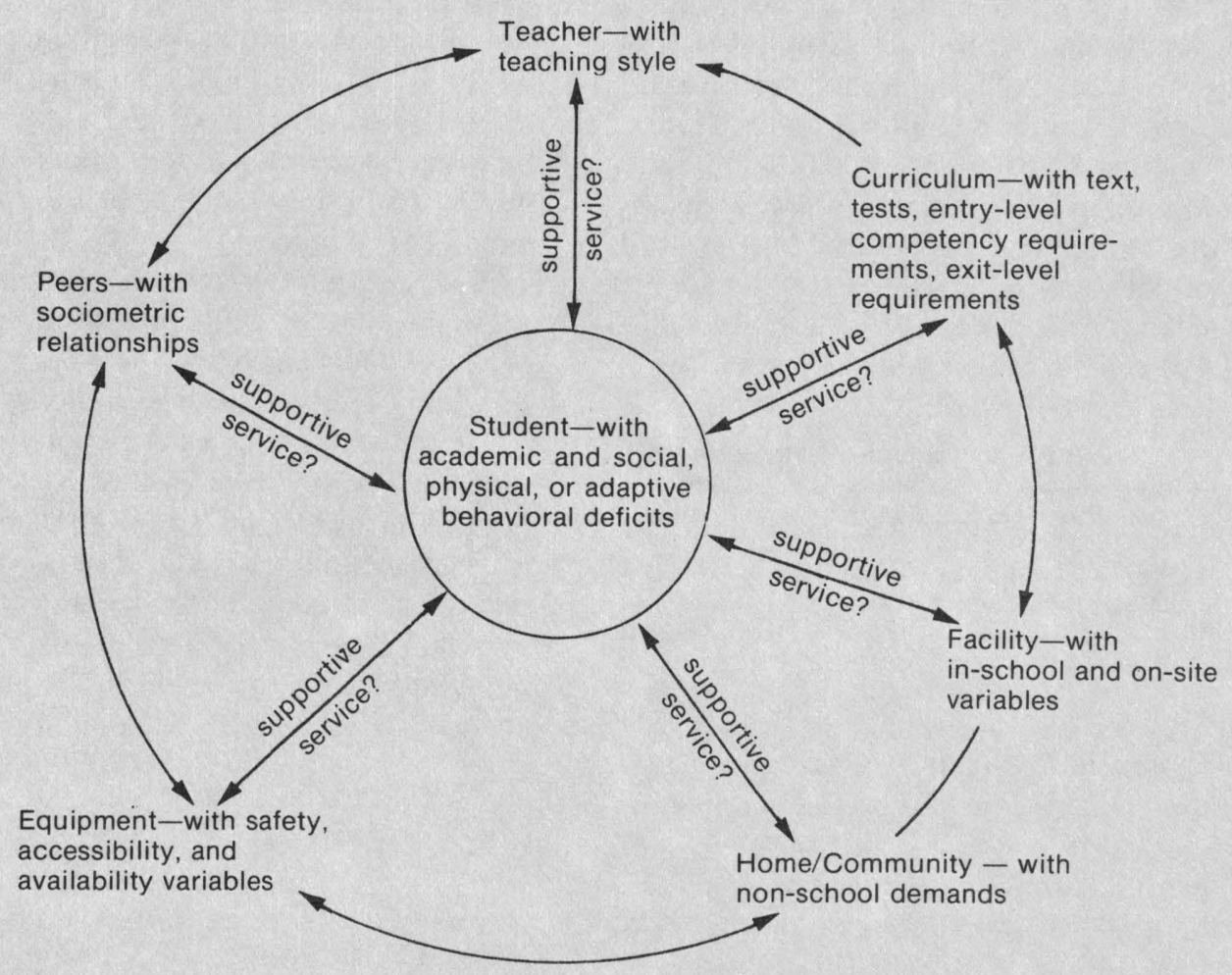

FIGURE 2

The Ecological Perspective for Program Planning

supportive services. Two underlying considerations are particularly important:

1. No handicapping condition exists in a student until he/she comes in contact with one or more program variables, and through an assessment of that contact, the need for support arises. Students are not handicapped until a deficit occurs in the manner in which they interact with some aspect of the school environment-what Gearheart and Weishahn (1984) called a "handicapping situation." That is why most mildly to moderately handicapped students "lose" their handicapping condition upon leaving the public schools.

2. Assessment of the contact between student and program variables can best occur through direct observation of that interaction. Granted, most IEPs are developed in the spring well in advance of the student's actual program placement, and much of this advanced program planning is guided by needed administrative efficiency. Nonetheless, we suggest that vocational assessors be guided in their program planning activities, to the maximum extent feasible, by direct observation of the student interacting in the classroom environment.

\section{Student-Curriculum Interaction}

To assess the interaction between a student and his/her placement curriculum, we suggest employing a 10-step strategy adapted from Zigmond, Vallecorsa, and Silverman (1983).

1. Decide what to assess. Many mildly handicapped students in mainstreamed vocational programs have to be assessed in basic academics. In addition, things such as general laboratory safety, performance in gross and fine motor operations, adaptive behavior, and knowledge of specific entry-level competencies unique to the curriculum may require attention as well.

2. Select or develop a skill hierarchy for each skill to be assessed. This step is most germane if the results of step 1 suggest a need to assess in either mathematics or in the performance of some sequenced task (e.g., finishing a piece of cabinetry or assembling a carburetor). Many commercially-developed vocational curricula, such as the Vocational-Technical Consortium of the States (V-TECS) guides, contain well-developed skill sequences in a large number of vocational offerings to assist assessors in developing performance-based skill hierarchies. 
3. Decide where to begin. Testing down rather than up, for speed and efficiency, is generally recommended. This would hold for mildly to moderately handicapped vocational education students, many of whom read and compute at better than fourth or fifth grade levels, and who many times possess significant technical knowledge in content areas. The point here is not to waste a lot of time testing students for skills they already have but, rather, let prior records (such as those in existing files and available from guidance personnel) and informal "quick" assessments dictate the likely upper limits of the area to be tested.

4. Select or develop the survey instrument. We recommend curriculum-referenced techniques, such as cloze procedures, for assessing a student's competence with the class text. If the course is competency-based (as are many vocational education curricula), competency checklists can provide excellent referents for instrument development to assess performance-related areas. Similarly, the V-TECS task analyses can provide valuable assistance, provided they are congruent with classroom-based task requirements. In general, criterion-referenced, informally-developed instruments are recommended (Albright, 1978b; Albright \& Hux, 1984).

5. Get ready to test. This is an especially important consideration for performance testing. With many students, observing the process of assessment in environments with naturally-occurring contingencies may be just as valuable in supportive service planning as is evaluation of results of the test itself.

6. Administer the survey. Again the student's performance and his/her process of completing the instrument are the primary considerations - not the score obtained.

7. Note errors and performance style. In many cases, noting the students' interaction with the laboratory environment as well as performance with the test will assist in interpretation of results and the most effective targeting of supportive services. It is also extremely important to consider the antecedents to the testing situation. Often, knowledge about a student's home life or classroom activity immediately prior to testing will temper the interpretation of results.

8. Analyze findings and summarize outcomes. Again, the goal is not to develop a score but, rather, to interpret findings in such a way as to develop hypotheses about supportive service needs. And as Halpern et al. (1982) suggest, reasonable performance levels for goals and objectives can begin to evolve through analysis and summary of outcomes, provided the focus is upon patterns of errors and single persistent errors (Zigmond et al., 1983).

9. Hypothesize reasons for errors and determine areas to probe. As Zigmond et al. (1983) have suggested, one must be certain that errors were not a result of disinterest or variables unrelated to the skills being tested, such as a poor night's sleep or anxiety over an upcoming test. If these kinds of exogenous variables appear to have influenced error patterns, results of the assessment should be discarded and arrangements made to redesign the testing environment. If, however, it is assured that the assessment reflects "motivated performance," the authors suggest four other possible hypotheses for errors: (a) the task was too complex; (b) the response mode was inappropriate; (c) the response level was too difficult, or (d) the student required cues/prompts. As was stated before, antecedents to testing should also be considered in developing hypotheses for errors.

10. Complete record keeping forms and generate teaching objectives. In all likelihood, annual goal statements will have been already identified prior to this 10step process. Albright (1978b) recommended development of annual goals and targeting areas for potential supportive services in the spring annual reviews, and developing specific short-term objectives and the intensity of the supportive services in the fall, shortly after classes begin. Assessment of student-curriculum interaction, if developed in this manner, engenders a high likelihood of resulting in an IEP that is a dynamic, useful management tool.

This 10-step strategy can be extremely valuable in developing specific objectives, reasonable criteria, and effective supportive services. We would also recommend, however, that vocational assessment specialists systematically examine the interaction of the curriculum, the facility/equipment, and the instructor's teaching style, specifically as they relate to entry-level skills required of program participants. Peterson and Housley (1982) have developed a relatively simple system for assessing these interactions, and documenting them on a "Training Analysis Form" for every vocational program available to special needs students. By referencing the results of specific assessments to information contained on that program's Training Analysis Form, targeted supportive services are likely to be more effective.

\section{Student-Teacher Interaction}

The interaction between handicapped students and regular classroom teachers has long been recognized as an important variable in the likely success of a mainstreamed placement and clearly should be assessed in program planning activities. Peterson and Housley's (1982) "Training Analysis Form," for example, has a section devoted to assessing teaching style. Also, knowledge of teacher attitudes, skills, and flexibility toward 
teaching handicapped students will have been taken into account in previous placement decisions. In program planning, we are particularly concerned with the teacher's ability to manage classroom behavior, to encourage positive student-student interaction (through the use of cooperative learning arrangements, buddy systems, or peer tutoring arrangements), and to individualize instruction for handicapped students in difficult units within the curriculum.

\section{Student-Student Interaction}

Johnson and Johnson (1978) provided an expanded definition of least restrictive placement that has important implications for program planning for some mainstreamed handicapped students:

\begin{abstract}
Mainstreaming is defined as providing an appropriate educational opportunity for all handicapped students in the least restrictive alternative, based on individualized educational programming and aimed at providing handicapped students with access to and constructive interaction with nonhandicapped peers. (p. 152)
\end{abstract}

For many handicapped students in vocational education classes, student-student interaction presents no problem; for others, it may. For students at risk, the vocational assessor will want to pay close attention to these interactions and plan support accordingly.

\section{Student-Facility/Equipment Interaction}

Consideration of this interaction is primarily relegated to planning programs for orthopedically, hearing, and vision impaired students. Voluminous guides of equipment modifications exist (e.g., Gugerty, Roshal, Tradewell, \& Anthony, 1981), and Erekson (1981) has developed a systematic approach for assessing facility/ equipment accessibility.

\section{Student-Home/Community Interaction}

Handicapped students, like all others, bring with them to school a complex mix of home/community interactions that can profoundly affect the efficacy of supportive service delivery in school. Vocational assessment specialists must be sensitive to these antecedent variables and determine as best they can their influence on a student's performance and how supportive services must be shaped around them.

\section{Monitoring Individual Progress}

Assessment for the purpose of monitoring individual progress has typically been ignored or addressed only perfunctorily in the vocational assessment literature (with a notable exception of Albright, 1978a). This is probably because it is difficult to monitor individual progress of handicapped students in a classroom setting when one's notion of vocational assessment is circumscribed by short-term administration of a battery of standardized instruments and commercial work samples. We suggest that vocational assessment specialists must include progress monitoring within their assessment domain, through training regular teachers, aides, or student mentors to collect data, or doing it themselves.

We recommend curriculum-based, direct, frequent, and informal measures to monitor progress. Ysseldyke, Thurlow, Graden, Wesson, Algozzine, and Deno (1983), reporting on 5 years of research on assessment for instructional decision-making, found that frequent 1-3 minute informal measures could reliably and validly monitor the quality of supportive service interventions. Earlier, Ysseldyke and Mirkin (1982) extolled the virtues of direct and frequent measurement:

\footnotetext{
Those who propose direct and continuous measurement. assume that no matter how carefully assessment might have been done initially, at the present time educational program planners are unable to predict which interventions will consistently have certain effects. . When direct and continuous measurement information is available to the teacher there is a higher probability the teacher will make better decisions, which in turn will lead to increased student achievement. (p. 399)
}

Van Etten and Van Etten (1976) have developed a relatively simple yet insightful model to measure student progress and have tested it empirically for its efficiency. It involves four elements. Continuous measures involve recording progress daily or every other day. Noncontinuous measures are those that are administered at regular intervals, such as every 6 weeks, at semester's end, or at the end of an instructional unit. Direct measures involve performance-based measurement in the same response mode as those used in the initial teaching of the skills. Indirect assessment means testing a student with related items that may not necessarily have been taught or may have been taught in a different response mode.

These distinctions have important implications for vocational assessment specialists in that handicapped students in vocational education programs frequently are taught performance-based skills (e.g., correctly taking blood pressure or installing new brake shoes), yet are required to demonstrate competence through written measures. Vocational assessors must sensitize regular vocational teachers to the difficulties of students who are placed in jeopardy by indirect measurement of competence, and they must cooperatively seek more direct measures. In any event, to the extent that we can generalize from the academic literature, vocational assessment 
PURPOSE

FUNCTION

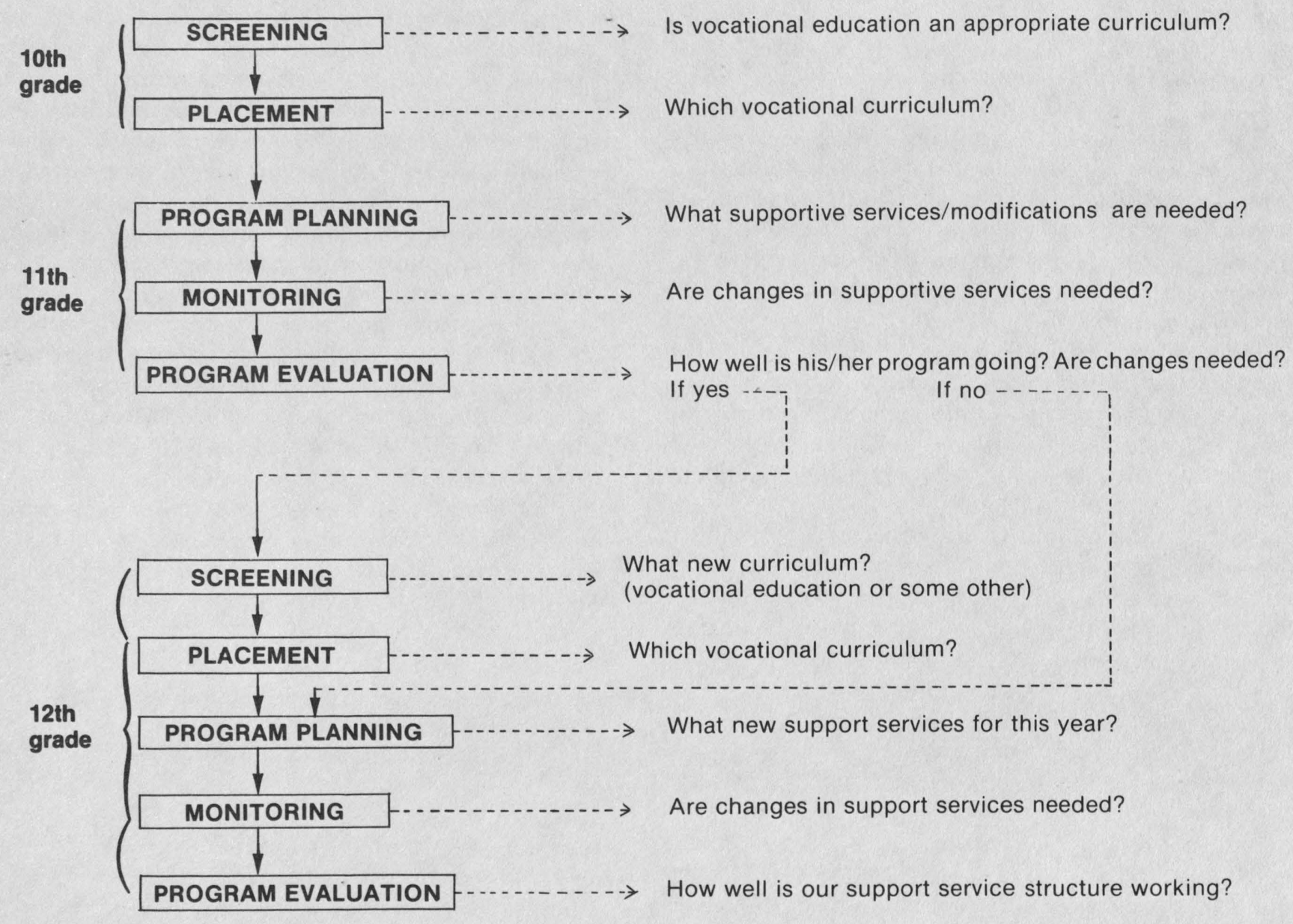

FIGURE 3

Chronological Sequence of Assessment Paradigm

specialists should include frequent and direct monitoring of student progress as part of their assessment domain for the students they serve.

\section{Individual Program Evaluation}

Assessment for individual program evaluation seeks to answer two interacting questions: "How well has the supportive service structure served this student?" and "Is a curriculum change warranted?" If a curriculum placement has not succeeded, the vocational assessment specialist must sort out whether the support service structure was inadequate or the placement simply was not right for the student. As with monitoring individual progress, evaluation should be based upon curriculum-referenced and direct measurement techniques.
Typically, this program evaluation occurs at semester's or year's end and, depending upon the outcome, will recycle the process. Figure 3 depicts a chronological sequence of how this assessment paradigm functions for a child throughout 3 years of vocational education. Some districts begin their vocational education programs in the ninth grade, which would extend the cycle one more year.

\section{CONCLUSION}

The foregoing discussion suggests some rather striking changes in vocational assessment for handicapped students in the public schools. We see these changes being characterized by two fundamental shifts in assessment 
service delivery, particularly as it relates to placement and training in vocational education.

\section{Vocational Evaluation Laboratories}

First, school districts that are operating, or considering operating, formal vocational evaluation laboratories should closely examine the expected outcomes (benefits) associated with those laboratories, and how well those benefits match teacher and student assessment needs. Vocational evaluation centers typically have high startup costs, require substantial staff to operate them, and utilize a fair amount of building space. Thus, to make them pay off, school districts must be certain that the benefits associated with operating these evaluation centers exceed the benefits that might accrue with some alternative allocation of operating budget, building space, and personnel.

Research examining costs and benefits of different vocational assessment models is virtually nonexistent. One study nearing completion (Neubert, 1984) does suggest that vocational assessment centers may function best is a screening/placement capacity, offering exploratory experiences to assist students in developing or refining areas of vocational interest (although Kiss, 1984, found no differences in career maturity for students who were recipients of a formal vocational assessment versus those who were not). Neubert also found little evidence of the results of a formal vocational assessment process being used to assist vocational or special educators in student program planning, monitoring, or evaluation. Similarly, articulation of assessment results into the present levels of performance sections of IEPs was virtually nonexistent.

We believe that in many school districts the vocational assessment needs of students and teachers alike may best be served by eliminating most commercial laboratory processes and involving assessment staff more directly in classroom environments, their curricula, and development of classroom-based performance samples directly related to those curricula. We believe most interviewing, document analyses, and interest testing can occur in vocational guidance offices. Similarly, direct observation of student behavior should clearly occur in normalized environments where handicapped students interact with the regular curriculum (or work setting) and its natural contingencies rather than with commerical work samples or in simulated work settings. We question the increasingly heavy reliance that vocational assessment specialists seem to be placing upon commercial assessment systems. Instead, we favor more informal, direct, and curriculum-based processes that reinforce interaction between assessors and teachers/support personnel rather than discourage it.

This recommendation for movement away from highly specialized vocational assessment laboratory activities has one important exception - the relatively new and promising area of rehabilitation engineering technology (see, for example, Hobson, 1984). We do not suggest that the public schools should begin to adopt these extremely expensive units. They are currently far too costly for the schools to absorb and presently serve only a small segment of the handicapped population - severely orthopedically impaired, blind, and deaf students. Nontheless, rehabilitation engineering does focus upon interactions between an individual and his/her natural work or home environment. This technology will likely spread into the schools and find utility in instructional or curricular modification for students with severe learning handicaps as well.

Our recommendation for reduced reliance upon vocational assessment laboratory processes is predicated upon the assumption that in its absence, more informal, classroom-based processes would replace it. We recognize, however, that in many cases alternative considerations might come into play that would render this assumption invalid. For example, in some districts elimination of a vocational assessment laboratory might result in elimination of staff associated with it. We obviously would not recommend that. Likewise, some districts use an extensive situational/work sample approach almost as an intervention to stimulate (as opposed to determine) vocational interests in handicapped students. While we would recommend short (1-2 week) mini-courses in actual vocational classrooms instead, we do recognize the importance of "hands-on" assessment activities to generate interest among students.

\section{Vocational Assessment Specialists}

The second major shift we envision is in the role and competencies of the vocational assessment specialist. We see the technical competencies necessary for the vocational assessment specialist to be things such as: (a) ability to function as part of a team whose responsibility is to synthesize information from diverse sources regular, vocational, special, and rehabilitation personnel - to make the most informed choices about students; (b) ability to consult with and train regular vocational education or special/vocational education teachers to monitor progress of handicapped students; (c) ability to interview students, parents, and other teachers to ascertain enduring vocational interests of individual handicapped students; (d) familiarity with all vocational curriculum options and their teacher's teaching styles and 
skills, as well as familiarity with community-based employment training alternatives; (e) ability to identify and direct modifications to curriculum, instructional delivery, and laboratory and equipment to accommodate mainstreamed students; and (f) ability to analyze the school/community supportive services system and orchestrate its utility for students served by the schools who will be in need of some form of transition services when they exit from it.

Clearly, these competencies describe an individual who spends a majority of his/her time outside the confines of a vocational assessment laboratory. They suggest a proactive, interventionist orientation, rather than a reactive, medical-model orientation. And they clearly suggest downplaying the predictive attempts of vocational aptitude testing in lieu of more short-term, intensive intervention planning. We envision, for example, our vocational assessment specialist's day beginning with traditional activities such as student interviewing, reviewing cumulative files, scheduling or organizing job shadowing or mini-tours of vocational courses, or informal interest testing. These traditional activities would then shift to visits to classrooms, home-based or telephone interviews with parents, community visits for job analyses and development, and monitoring of students who have been placed in the community. In short, this individual's skills fit the description of any highly trained supportive service personnel. The difference is that this person fits his/her activities into a vocational assessment paradigm, and that each activity fulfills a purpose within it.

This article has examined the vocational assessment process as it relates primarily to mainstreamed, in-school vocational education. Some of these paradigmatic components would change significantly or even disappear under other service delivery alternatives. For example, if a school district places all ninth grade children labeled educable mentally retarded in a prevocational program, the need for assessment for purposes of screening and placement is eliminated and assessment for program planning is sharply reduced. Similarly, many handicapped students who are likely candidates for mainstreamed vocational education programs could also fit into other nonrestrictive placements, such as communitybased employment training programs.

The intensity with which a vocational assessor engages in different assessment purposes varies throughout a student's vocational education program. For example, at the beginning of a student's 2-year program, the assessor would want to make certain that screening and placement purposes were well met. Program planning and monitoring would receive attention continually throughout the student's program, and program review probably would not occur until the end of the first year. If the program is successful, assessment for screening and placement the following year is not necessary, since most vocational curriculum sequences are fairly well-defined after initial selection. As a student nears the end of a program, however, assessment for screening and placement (for CWE or transitional planning) again becomes of much more concern.

\section{REFERENCES}

Albright, L. (1978a). Monitoring the student's individualized vocational plan. In L. Albright, J. Fabac, \& R. Evans (Eds.), A system for the identification, assessment, and evaluation of the special needs learner in vocational education. Urbana-Champaign: University of Illinois, Bureau of Educational Research.

Albright, L. (1978b). Strategies for assessing the student's present level(s) of performance. In L. Albright, J. Fabac, \& R. Evans (Eds.), A system for the identification, assessment, and evaluation of special needs learners in vocational education. Urbana-Champaign: University of Illinois, Bureau of Educational Research.

Albright, L., (1979). Administering programs for handicapped students (Professional Development Series, No. 3). Arlington, VA: American Vocational Association.

Albright, L., Fabac, J., \& Evans, R. (1978). A system for the identification, assessment, and evaluation of the special needs learner in vocational education. Urbana-Champaign: University of Illinois, Bureau of Educational Research.

Albright, L., \& Hux, T. (1984, February). Program aids in IEP development. School Shop, 22-23.

Arizona Department of Education. (1982). Arizona model for vocational assessment: A procedural manual. Phoenix: Author.

Batsche, C. (1982). Handbook for vocational school psychology. Des Moines: Iowa Department of Public Instruction.

Bellamy, G.T., \& Wilcox, B. (1982). Secondary education for severely handicapped students: Guidelines for quality services. In K.P. Lynch, W.E. Kiernan, \& J.A. Stark (Eds.), Prevocational and vocational education for special needs youth: A blueprint for the 1980s. Baltimore: Paul H. Brookes.

Botterbusch, K.F. (1978). A guide to job site evaluation. Menomonie: University of Wisconsin-Stout, Stout Vocational Rehabilitation Institute.

California State Department of Education. (1983). Career/vocational assessment of California secondary students with exceptional needs. Sacramento: Office of Special Education.

Cobb, R.B. (1981). Vocational assessment of the special needs learner: The utility of commercial work sampling systems. Journal of Vocational Special Needs Education, 3(3), 30-32.

Cobb, R.B. (1983). A curriculum-based approach to vocational assessment. Teaching Exceptional Children, 15(9), 216-219.

Dahl, T., Appleby, J., \& Lipe, D. (1978). Mainstreaming guidebook for vocational educators teaching the handicapped. Salt Lake City, UT: Olympus Publishing.

Dunn, D.J. (1976, October). What occupations or jobs will the individual be successful at in the future? In D.J. Dunn, T.A. Korn, \& J. Andrew (Eds.), Critical issues in vocational evaluation. Menomonie: University of Wisconsin-Stout, Stout Vocational Rehabilitation Institute.

Dunn, D., Korn, T., \& Andrew, J. (Eds.). (1976). Critical issues in vocational evaluation. Menomonie: University of Wisconsin-Stout, Stout Vocational Rehabilitation Institute.

Erekson, T.L. (1981, January). Accessibility to laboratories and equipment for the physically handicapped: $A$ handbook for vocational education personnel. DeKalb: Northern Illinois University, College of Education.

Evans, R.N., \& Herr, E.L. (1978). Foundations of vocational education (2nd ed.). Columbus, $\mathrm{OH}$ : Charles E. Merrill 
Gearheart, B.R., \& Weishahn, M.W. (1984). The exceptional student in the regular classroom (3rd ed.). St. Louis: Mosby.

Gugerty, J.J., \& Crowley, C.B. (1982). Informal vocational assessment for special needs students. Journal of Vocational Special Needs Education, 4(2), 16-18.

Gugerty, J.J., Roshal, A.F., Tradewell, M.D.J., \& Anthony, L. (1981, January). Tools, equipment and machinery adapted for the vocational education and employment of handicapped people. Madison: University of Wisconsin, Stout Vocational Studies Center.

Halpern, A.S., Lehmann, J.P., Irvin, L.K., \& Heiry, T.J. (1982). Contemporary assessment for mentally retarded adolescents and adults. Baltimore: University Park Press.

Hasazi, S.B., \& Gordon, L.R. (1982). Follow-up study of graduatesleavers of diversified education programs in Vermont. Montpelier: Vermont State Department of Education.

Hawkins, R.P. (1979). The functions of assessment: Implications for selection and development of devices for assessing repertoires in clinical, educational, and other settings. Journal of Applied Behavior Analysis, 12(4), 501-516.

Hobson, J. (1984). Rehabilitation engineering - a developing speciality. Prosthetics \& Orthotics International, 1, 56-60.

Hohenshil, T.H. (1984). School psychologists facilitating career development programs in secondary education. Career Development for Exceptional Individuals, 7(2), 51-58.

Hohenshil, T.H., Anderson, W.T., \& Salwan, J.W. (Eds.). (1982). Secondary school psychological services: Focus on vocational assessment procedures for handicapped students. Blacksburg: Virginia Polytechnic Institute and University, College of Education.

Johnson, D.W., \& Johnson, R.T. (1978). Mainstreaming: Will handicapped students be liked, rejected, or ignored? Instructor, 87 . 152-154.

Kiernan, W.E., \& Petzy, V. (1982). A systems approach to career and vocational education programs for special needs students grades 7-12. In K.P. Lynch, W.E. Kiernan, \& J.A. Stark (Eds.), Prevocational and vocational education for special needs youth: A blueprint for the 1980s. Baltimore: Paul H. Brookes.

Leinhardt, G.. Bickel, W., \& Pallay, A. (1982). Unlabeled but still entitled: Toward more effective remediation. Teachers College Record, 84(2), 391-422.

Lilly, M.S. (1983, August). Divestiture in special education: An alternative model for resource and support services. UrbanaChampaign: University of Illinois, College of Education.

Maryland State Department of Education. (1980). Vocational student assessment. Baltimore: Division of Vocation-Technical Education.

Menchetti, B.M., Rusch, F.R., \& Owens, D.M. (1982). Assessing the vocational training needs of mentally retarded adults. In J.L. Matson, \& S.E. Breuning (Eds.), Assessing the mentally retarded. New York: Grune \& Stratton.

Messick, S. (1984). Assessment in context: Appraising student performance in relation to instructional quality. Educational Researcher, 13(3), 3-8.

Miller, S.R., Sachs, J.J., \& Stadt, R. (1982). Assessment of secondary exceptional students' vocational interests and aptitudes: Need, status, and recommendations. ICEC Quarterly, 3l(4), 13-19.

Neubert. D. (1984). A study of vocational evaluation recommendations used in the educational planning and placement process for handicapped students (preliminary data analysis). Unpublished doctoral dissertation. University of Maryland, Department of Industrial, Technological, and Occupational Education, College Park.

Peterson. M. (1982, December). Vocational assessment of the visually impaired. Paper presented at the annual meeting of the American Vocational Association, Anaheim, CA.

Peterson, M., \& Hill, P. (1982). Vocational assessment of students with special needs: An implementation manual. Commerce: East Texas State University, Occupational Curriculum Laboratory.

Peterson, M., \& Housley, W. (1982). Entry skills needed for special needs students in vocational programs. Vocational Guidance Quarterly, 149-153.

Petzy, V. (1983). Vocational assessment for special needs students in the middle/junior high school. Career Development for Exceptional Individuals, 6(1), 15-24.
Phelps, L.A. (1982, May). Testimony delivered before the joint hearing of the Subcommittee on Elementary, Secondary, and Vocational Education and the Subcommittee on Select Education of the Committee on Education and Labor. Washington, DC: U.S. Government Printing Office.

Phelps, L.A.. \& McCarty, T. (1984). Student assessment practices. Career Development for Exceptional Individuals, 7(1), 30-37.

Phelps, L.A., \& Wentling, T.L. (1977). A proposed system for the identification, assessment, and evaluation of special needs learners. Journal of Industrial Education, 14(3), 19-35.

Rosenberg, H., \& Tesolowski, D.G. (1982). Assessment of critical vocational behaviors. Career Development for Exceptional Individuals, 5(1), 25-37.

Salvia, J., \& Ysseldyke, J.E. (1981). Assessment in special and remedial education (2nd. ed.). Boston: Houghton Mifflin.

Schneck, G.R. (1981, June). Program improvement in vocational assessment for the handicapped. In R.A. Stodden (Ed.), Vocational assessment (Policy Paper series, Document 6). Urbana-Champaign: University of Illinois, Leadership Training Institute/Vocational and Special Education.

Shepard, J.W., Dielman, M.B., \& Ellenwood, A.E. (1984). School psychologists and vocational education programs. Participation in career development for the handicapped. Journal for Vocational Special Needs Education, 6(2), 13-14; 22.

Sitlington, P.L., \& Wimmer, D. (1978). Vocational assessment techniques for the handicapped adolescent. Career Development for Exceptional Individuals, I(2), 74-87.

Snow, R.E. (1984). Placing children in special education. Some comments. Educational Researcher, 13(3), 12-14.

Stern, D. (1984). School-based enterprise and the quality of work experience: A study of high school students. Youth \& Society, 15(4), 401-427.

Stodden, R.A., \& lanacone, R.N. (1981). Career/vocational assessment of the special needs individual: A conceptual model. Exceptional Children, 47(8), 600-608.

Thurlow, M.L., \& Ysseldyke, J.E. (1982). Instructional planning: Information collected by school psychologists vs. information considered useful by teachers. Journal of School Psychologl, 20(1), 3-10.

Van Etten, C., \& Van Etten, G. (1976). The measurement of pupil progress and selecting instructional materials. Journal of Learning Disabilities, 9(8), 469-480.

Wright, A.R., Cooperstein, R.A., Renneker, E.G., \& Padilla, C. (1982, December). Local implementation of P.L. 94-142: Final report of a longitudinal study (SRI Project 7124). Menlo Park, CA SRI International Social Sciences Center.

Ysseldyke, J.E., \& Mirkin, P.E. (1982). The use of assessment information to plan instructional interventions: A review of research. In C.R. Reynolds \& T.B. Gutkin (Eds.). The handbook of school psychology: New York: John Wiley \& Sons.

Ysseldyke, J.E., Thurlow, M., Graden, J., Wesson, C., Algozzine, B., \& Deno, S. (1983). Generalizations from five years of research on assessment and decision making: The University of Minnesota Institute. Exceptional Education Quarterly, 4(1), 75-93.

Zigmond, N., Vallecorsa, A., \& Silverman, R. (1983). Assessment for instructional planning in special education. Englewood Cliffs, $\mathrm{NJ}$ : Prentice-Hall.

Zytowski, D. (1982). Assessment in the counseling process for the 1980's. Measurement \& Evaluation in Guidance, 15(1), 15-20.

Dr. Cobb's contribution to this manuscript was supported by an award from the University of Maryland General Research Board. The authors wish to thank the following individuals for their insightful and incisive comments on earlier drafts of this manuscript: Len Albright, Barbara and John Banks, Susan Brody-Hasazi, Pat Decoteau, Nishma Duffy, Pam Leconte, Deb Neubert, Mike Peterson, Al Phelps, and Pat Sitlington. 


\section{computer update}

\author{
By Barbara Thomspon, Jerry Chaffin, and \\ Bill Maxwell
}

A number of interesting pieces of information have recently crossed our desks. We have selected several to share with you this month.

\section{Federally Sponsored Research with Microcomputers}

Computer Education: A Catalog of Projects sponsored by the U.S. Department of Education, 1983 is a catalog of one-page abstracts describing 275 different funded projects that were ongoing in 1983. Edited by Susan Klein, the abstracts don't provide detailed information, but they do, in most cases, give the reader a good general overview of each project. Names and addresses are provided for readers who care to follow up for more complete information.

The projects cover a wide range of applications including computer literacy, software development, and research. We were impressed, quite frankly, with the number and wide range of microcomputer applications that are currently ongoing in American schools.

Administrators, supervisors, or teachers who have a special interest in microcomputer applications should find this manual both interesting and useful. It can be obtained from the Superintendent of Documents (no cost was indicated) or perhaps from your senator or representative.

\section{Microcomputer Usage in Schools}

Computer + Software News recently reported the results of a survey of the top 50 school districts in the U.S. and the kind of microcomputers currently in use in their districts. The survey, conducted by Quality Education Data (QED), found that Apple continues to dominate the microcomputer market in schools. The results were:

$\begin{array}{lr}\text { Apple } & 47.9 \% \\ \text { Radio Shack } & 22.4 \% \\ \text { Commodore } & 10.8 \% \\ \text { IBM } & 6.0 \% \\ \text { Atari } & 4.4 \% \\ \text { Texas Instruments } & 4.3 \% \\ \text { Franklin } & 2.9 \% \\ \text { Other } & 1.5 \%\end{array}$

The report also noted that the ratio of microcomputers to pupils has been cut in half in just one year; the ratio was 1 to 170 during the 1983-84 school year and is now 1 to 85 . Encouraging, yes, but given a 6-hour school day, the current ratio still computes to only about 4 minutes per day per pupil.

\section{Standardized Computer System}

The Maryland state school system is considering implementation of a plan that involves a standardized computer system in all public schools. According to a briefing in Education Computer News (November 21, 1984), a technology company, National Information Utilities Corporation in Vienna, Virginia, has developed the plan, which would use public television to broadcast video and computer data. A central storage computer in each school could access the data and transmit it to terminals in the classrooms. For example, textbooks, workbooks, software packages, electronic encyclopedias, and other CAI systems could be received. Teachers would be able to select appropriate on-line materials for each of their students.

According to the plan, each district that participates would buy or lease the terminals and pay royalties for the programs that are used. According to the briefing, Maryland has shown a great deal of positive interest, and districts in other states have also expressed interest in this system.

\section{National Software Evaluation Consortium}

The September, 1984, issue of Micro Market Examiner reported the outcomes of the Special Education Technology Conference for SEA directors conducted by Education TURNKEY Systems. According to this report, one of the most important outcomes was the planning of a national consortium for software evaluation. Activities will initially include the development of uniform courseware screening evaluations, and selection criteria. The criteria are intended for use among special education consumers and as specifications for electronic publishers and developers for the special education market.

States and individuals who are currently involved in leadership roles in the consortium include: Dr. Judith Wilson, Project MICC, Kansas; Dr. Eileen Pracek, FOLARS, Florida; Dr. Chauncey Rucker and Dr. Christie Davis, CONNSENSE, Connecticut; and Dr. Kim Allard, Project SECTOR, Utah State University. 


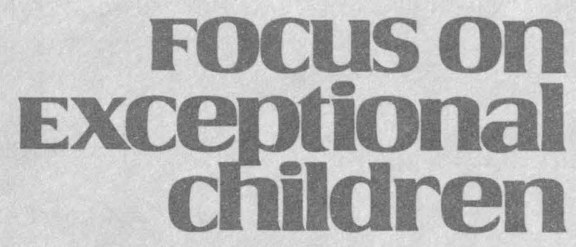

\section{A classic book that looks ahead...}

\section{Samuel A. Kirk and James C. Chalfant}

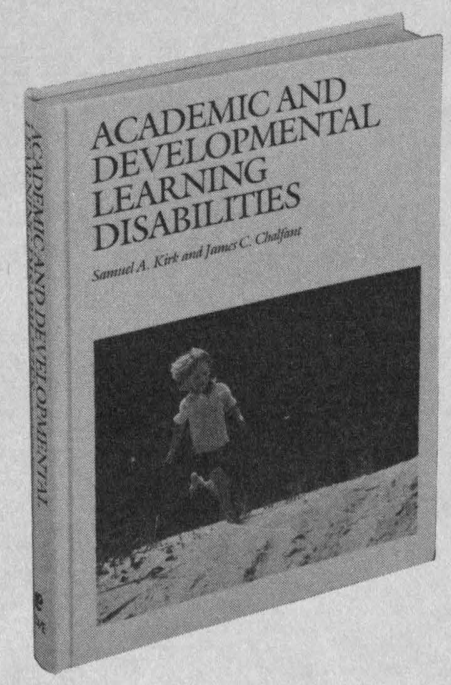

\section{SPECIAL FEATURES}

- The book emphasizes practical application of knowledge to classroom situations and usefulness to the teacher.

- Various points of view are explored so that readers may objectively synthesize the information.

- It is informative and practical in its discussion of informal assessment techniques and instructional methods.

- The relationship of developmental and academic considerations is brought together and analyzed for the reader.

- The book looks ahead. What are the probable trends and where is the field going?

- The authors have unparalleled experience in the field. No other combination is as well qualified.

- The book says what should be said. It is brightly written with a fresh personality.

\section{ACADEMICAND DEVELOPMENTAL LEARNING DISABILITIES}

This very practical and special book covers definitions, classifications, causes, and contributing factors of learning disabilities. It includes diagnosis, guidelines for assessment, and remediation strategies. It was written for teachers in regular grades as well as special teachers in programs for the learning disabled.

The authors have classified the field into the two major areas of developmental and academic learning disabilities. Developmental learning disabilities are those of attention, memory, perception, thinking, and oral language. Academic disabilities involve problems with reading, handwriting, spelling and written expression, and arithmetic.

Developmental learning disabilities are identified at the pre-school and school-age levels. Academic learning disabilities are identified at the school-age level. The book includes current issues such as self-esteem, social behavior, and delinquency. It takes a fresh, lucid approach to learning disabilities.

No. $8401 /$ hardback

\section{LOVE PUBLISHING COMPANY} 1777 South Bellaire Street Denver, Colorado 80222 